\title{
INJURIES SUSTAINED IN RUGBY BY WEARERS AND NON-WEARERS OF MOUTHGUARDS
}

\author{
J. B. BLIGNAUT, BChD(Hons), I. L. CARSTENS, BDS, HDipDent and C. J. LOMBARD, MSc, PhD* \\ Department of Community Dentistry, University of Stellenbosch, R.S.A. and *Institute for Biostatistics, Medical Research Council, Tygerberg
}

\section{ABSTRACT}

Previous studies have shown a higher prevalence of head and neck injuries in non-wearers when compared with wearers of mouthguards. The purpose of the present study was to compare the pattern of injuries to those of past studies and also to investigate whether the injuries sustained differed significantly between wearers and non-wearers. A sample of 321 university students participating on $\mathbf{5 5 5}$ player occasions was studied in a cross-sectional survey. No statistically significant differences ( $p>0.05$ ) were found between wearers and non-wearers of mouthguards with respect to head and neck injuries in general and to oral injuries in particular. We conclude that injuries sustained at rugby in this study were not associated with the use or non-use of mouthguards.

Key words: Rugby injuries; Prevention; Mouthguards.

\section{INTRODUCTION}

Contact sports cause many injuries (Myers, 1980; Josell and Abrams, 1982). A contact sport such as rugby lends itself to many injuries (Cathcart, 1952; Nicholas, 1980), many are oral and dental and occur frequently (Moon and Mitchell, 1961; Clegg, 1969; Blignaut and Carstens, 1984). When compared with other traumatic injuries to the body, oral and dental injuries are considered less serious. Teeth however have a very low potential of recovery to the normal functional state and therefore injuries of the teeth demand immediate evaluation and treatment (Casteldi, 1981). These injuries can be almost totally avoided by the use of a protective apparatus such as a mouthguard (Moon and Mitchell, 1961; Heintz, 1968; Brebner and Marshall, 1977; Morton and Burton, 1979; de Wet et al, 1981; Nicholas, 1981; Josell and Abrams, 1982; Chapman, 1985b). Although mouthguards are regarded as protective devices for the oral structures, proof of its effectiveness is often subjective (Davies et al, 1977; Morton and Burton, 1979; Myers, 1980; Upson, 1982).

\section{METHODS}

First-team players from the residence league, University of Stellenbosch, participated in the project. Six examiners explained the aims and objectives of the project to all players participating and then motivated them to answer all questions honestly and accurately. Before and after every match the particulars were recorded on a computerised form. Prior calibration of the examiners were done at two matches and a very high reproducibility of results were obtained. Written consent for the project was obtained from the university authorities and rugby directorate.

\section{RESULTS}

321 players participated in the project on 555 player occasions (one rugby match involving 30 players $=30$ player occasions). Matches were mostly played at Coetzenburg, the rugby fields of the University at Stellenbosch ( $86.5 \%$ of the player occasions). The ages of the players ranged from 18 to 29 years with an average age of 22 years for the sample. Players wore mouthguards for $194(35 \%)$ of the player occasions and a varying pattern of use was observed for the different teams. Dentists provided almost $95 \%$ of all mouthguards.

Address for correspondence:

Professor I. L. Carstens

Private Bag 11

PO Tygerberg 7505

South Africa
Eighty-seven players sustained a total of 98 head and neck injuries. Soft tissue injuries were the most prevalent $(79.6 \%)$ and of these $26(33.3 \%)$ were cuts, $21(26.9 \%)$ lacerations and $31(39.7 \%)$ bruises. Lips were the most vulnerable area being involved in $16(20.5 \%)$ of cases. Concussion comprised $15(15.3 \%)$ of all head and neck injuries (Table I). Hard tissue injuries were only found in 5 cases $(5.1 \%)$; teeth being involved in 4 of the latter. Only 1 fractured and 1 subluxed tooth were found in each jaw. The remaining hard tissue injury involved the nose.

TABLE I

Prevalence of specific injuries.

\begin{tabular}{lccc}
\hline Injury & $\mathrm{N}$ & \% of Total Injuries \\
\hline $\begin{array}{l}\text { Soft Tissue } \\
\text { Mouth } \\
\text { Lips }\end{array}$ & 78 & & 79.6 \\
$\begin{array}{l}\text { Hard Tissue } \\
\text { Teeth } \\
\text { Bone }\end{array}$ & 5 & 16 & 5.1 \\
$\begin{array}{l}\text { Concussion } \\
\text { Total }\end{array}$ & 15 & 1 & 15.3 \\
\hline
\end{tabular}

The prevalence of injuries for the groups of wearers and non-wearers, were then compared statistically by means of the Chi-square test (Table II). There was no association between usage/non-usage of mouthguards and head and neck injuries $\left(\chi^{2}\right.$-test, $\left.p=0.91\right)$. Of the 149 players who wore mouthguards $30(15.5 \%)$ were injured, whilst $57(15.8 \%)$ of the 361 non-wearers sustained injuries. Similar nonsignificant results prevailed for an injury such as concussion ( $\chi^{2}$-test, $p=0.67$ ) (Table III).

The prevalence of head and neck injuries (including concussion) could be due purely to chance. However, when attention is focussed on more specific injuries which may have a greater direct association with the use or non-use of mouthguards such as oral, dental and lip injuries, we again found negligible differences between wearers and nonwearers of mouthguards ( $\chi^{2}$-test, $p=0.97$ ) (Table IV). This left the results of hard tissue injuries, especially those injuries to the teeth, to be analysed. Because the latter injuries were however so few in number no point could be served by analysing the data statistically. However, it needs to be mentioned that an equal number of injuries to teeth (2) were noted in both wearers and non-wearers. 
TABLE \|

Mouthguard usage relative to head and neck injuries.

\begin{tabular}{|c|c|c|c|c|c|c|c|}
\hline \multirow{2}{*}{\multicolumn{2}{|c|}{$\begin{array}{l}\text { Mouthguard } \\
\text { Usage }\end{array}$}} & \multicolumn{6}{|c|}{ Injuries } \\
\hline & & \multicolumn{2}{|c|}{ No } & \multicolumn{2}{|c|}{ Yes } & \multicolumn{2}{|c|}{ Total } \\
\hline Column \% & Row \% & $\mathbf{N}$ & $\%$ & $\mathbf{N}$ & $\%$ & $\mathbf{N}$ & $\%$ \\
\hline & & & 35.0 & & 4.5 & & \\
\hline \multirow[t]{2}{*}{ Yes } & & 164 & 84.5 & 30 & 15.5 & 194 & 35.0 \\
\hline & & & 65.0 & & 5.6 & & \\
\hline \multirow[t]{2}{*}{ No } & & 304 & 84.2 & 57 & 15.8 & 361 & 65.0 \\
\hline & & & 00.0 & & 0.0 & & \\
\hline Total & & 468 & 84.3 & 87 & 15.7 & 555 & 100.0 \\
\hline
\end{tabular}

$\chi^{2}=0.010$ DF $=1 \quad P=0.9199$

\section{TABLE III}

Mouthguard usage relative to concussion.

\begin{tabular}{|c|c|c|c|c|c|c|c|}
\hline \multirow{2}{*}{\multicolumn{2}{|c|}{$\begin{array}{l}\text { Mouthguard } \\
\text { Usage }\end{array}$}} & \multicolumn{6}{|c|}{ Injured } \\
\hline & & & No & & & & tal \\
\hline \multirow[t]{2}{*}{ Column \% } & Row \% & $\mathbf{N}$ & $\%$ & $\mathbf{N}$ & $\%$ & $\mathbf{N}$ & $\%$ \\
\hline & & & 34.8 & & 0.0 & & \\
\hline \multirow[t]{2}{*}{ Yes } & & 188 & 96.9 & 6 & 3.1 & 194 & 35.0 \\
\hline & & & 65.2 & & 0.0 & & \\
\hline \multirow[t]{2}{*}{ No } & & 352 & 97.5 & 9 & 2.5 & 361 & 65.0 \\
\hline & & & 100.0 & & 0.0 & & \\
\hline Total & & 540 & 97.3 & 15 & 2.7 & 555 & 100.0 \\
\hline
\end{tabular}

$\chi^{2}=0.173 \quad$ DF $=1 \quad P=0.6778$

TABLE IV

Mouthguard usage relative to mouth, lip and tooth injuries.

Mouthguard

Usage

\begin{tabular}{|c|c|c|c|c|c|c|c|}
\hline \multirow[b]{2}{*}{ Column \% } & \multirow[b]{2}{*}{ Row \% } & \multicolumn{2}{|c|}{ Not Injured } & \multicolumn{2}{|c|}{ Injured } & \multicolumn{2}{|c|}{ Total } \\
\hline & & $\mathbf{N}$ & $\%$ & $\mathbf{N}$ & $\%$ & $\mathbf{N}$ & $\%$ \\
\hline & & & 35.0 & & 34.6 & & \\
\hline \multirow[t]{2}{*}{ Yes } & & 185 & 95.4 & 9 & 4.6 & 194 & 35.0 \\
\hline & & & 65.0 & & 65.38 & & \\
\hline \multirow[t]{2}{*}{ No } & & 344 & 95.3 & 17 & 4.7 & 361 & 65.0 \\
\hline & & & 100.0 & & 100.0 & & \\
\hline Total & & 429 & 95.3 & 24 & 4.7 & 555 & 100.0 \\
\hline
\end{tabular}

$\chi^{2}=0.001 \quad D F=1 \quad P=0.9703$

\section{DISCUSSION}

It is a known fact that contact sports are the cause of many injuries. It is also a fact that a particularly high number of injuries are sustained at rugby (Myers, 1980; Chapman, 1985a).

It is specifically stated that mouthguards render great protection and may totally prevent or limit the number and degree of injuries (Brebner and Marshall, 1977). The authors are inclined to agree with the philosophy underlying this statement but because the results of the present study differ so radically from it, further clarification is necessary. One possible explanation is that assumptions and comparisons are often based on injuries sustained in American Football (Stenger et al, 1964; Gelbier, 1966; Clegg, 1969; Blum and Krantz, 1982). Although American Football is recognised as a prime contact-sport, the style differs from that of amateur rugby as played in the Republic of South Africa. The prevalence of injuries in these two sports are therefore probably not comparable.

Another problem factor concerns the design of the research project. In certain studies thorough examinations were done with the help of mirrors and probes before and after matches and also at the start and end of the season. Unfortunately and without exception, information on the use of mouthguards was collected by making use of questionnaires which amounts to retrospective tabulation of data (Dennis and Parker, 1972; Davies et al, 1977; Morton and Burton, 1979; Nicholas, 1976; de Wet et al, 1981 and Blignaut and Carstens, 1984; Chapman, 1985a; Chapman, 1985b). This implies a memory test. Another problem was that in only one report on British adult rugby injuries was the author mentioned to be present personally at matches (Walkden, 1975).

Statistical analysis of the data in some of the aforementioned surveys even went so far as to provide significant differences between wearers and non-wearers of mouthguards.

The authors are thus of the opinion that little value could be attached to the results of previous studies mainly because of the subjectivity caused by retrospective design.

On self-examination of our own design and after many discussions with biostatisticians on the subject, certain aspects need further discussion and explanation. Firstly we admit that hidden or latent injuries could have been missed as no intensive oral examinations were done with mirror and probe before and after each match. It is a known fact that symptoms and signs often only manifest months and years after teeth have been traumatised. Fractures may also remain undetected without the use of X-rays (Gelbier, 1966). We are, however, of the opinion that although such examinations may have refined the data, it would not necessarily have affected the results because of the thoroughness of the interview and the co-operation of the players with the intensive questioning.

\section{CONCLUSIONS}

It appears that the use or non-use of mouthguards had no statistically significant effect on the prevalence of injuries to oral and dental tissues in this study. The general assumption that mouthguards prevent oral and dental injuries seems over-rated, since sufficient proof is lacking. One could also argue that the construction of mouthguards for players in this study is not cost-effective and that the provision to players be re-evaluated. However before such a drastic general conclusion is reached further similar research is necessary. We are of the opinion that the Stellenbosch method of educating the players on the ethics of the game and the strict application of the rules may have had a decisive effect on the prevention of oral and dental injuries.

\section{ACKNOWLEDGEMENTS}

The authors wish to thank the rugby directorate and players 
of the University of Stellenbosch for their esteemed co-operation. They also wish to express thanks to Miss R. van Wyk from the Instititute of Biostatistics, M.R.C. for helping with the analysis and also Mmes. B. de Wet and M. Geyer for their excellent secretarial support.

\section{References}

Blignaut, J. B. and Carstens, I. L., 1984. Unpublished data.

Blum, J. and Kranz, S., 1982 "Operation Mouthguard: A Model program designed to prevent dental trauma". Journal of Dentistry for Children, Jan.-Feb.: 22-24.

Brebner, R. T. S. and Marshall, D. W., 1977 "Mouthguards - A Community project". New Zealand Dental Journal 73: 61-63.

Casteldi, C., 1981 "Injuries to teeth". In Vinger, P. F. and Hoerner, E. F. (Eds.): Sports injuries: The Unthwarted Epidemic. Littleton, Mass., PSG Publishing Co., Inc.

Cathcart, J. F., 1952 "The use of mouth protectors for contact sports". Dental Digest 57: 348-350.

Chapman, P. J., 1985a "Orofacial injuries and the use of mouthguards by the 1984 Great Britain Rugby League touring team". Brit.J.Sports Med. 19: 34-36.

Chapman, P. J., 1985b "Orofacial injuries and mouthguards: a study of the 1984 Wallabies". Brit.J.Sports Med. 19: 93-95.

Clegg, J. H., 1969 "Mouth protection for rugby football players". British Dental Journal 127: 341-343.

Davies, R. M., Bradley, D., Hale, R. W., Laird, W. R. E. and Thomas, P. D., 1977 "The Prevalence of dental injuries in Rugby Players and their attitude to mouthguards". Brit.J.Sports Med. 11: 72-74. de Wet, F. A., Badenhorst, M. and Rossouw, L. M., 1981 “Mouthguards for rugby players at primary school level". Journal of the Dental Association of South Africa 36: 249-253.

Dennis, G. J. and Parker, D. A. S., 1972 "Mouthguards in Australian Sport. Australian Dental Journal". 17: 228-235.

Gelbier, S., 1966 "The use and construction of mouth and tooth protectors for contact sports". British Dental Journal 120: 533-537.

Heintz, W. D., 1968 "Mouth protectors - a progress report". Journal of the American Dental Association 77: 632-636.

Josell, S. D. and Abrams, R. G., 1982 "Traumatic injuries to the dentition and its supporting structures". Pediatric Clinics of North America 29 (3): 738-741.

Myers, P. T., 1980 "Injuries presenting from Rugby Union Football". Med.J.Aust. 2: 17-20.

Moon, D. G. and Mitchell, D. F., 1961 "An evaluation of a commercial protective mouthpiece for football players". JADA 62: 568-572.

Morton, J. G. and Burton, J. F., 1979 "An evaluation of the effectiveness of mouthguards in high school rugby players". New Zealand Dental Journal 75: $151-153$.

Nicholas, N. K., 1980 "Dental injuries in primary and intermediate school children". New Zealand Dental Journal 76: 8-11.

Nicholas, N. K., 1982 "Mouth protection for children". New Zealand Dental Journal 78: 62-64.

Stenger, J. M., Lawson, E. A., Wright, J. M. and Ricketts, J., 1964 "Mouthguards: Protection against shock to head, neck and teeth". JADA 69: 273.

Upson, N., 1982 "Dental injuries and the attitudes to mouthguards". Brit.J. Sports Med. 16: 241-244.

Walkden, L., 1975 "The Medical hazards of Rugby Football". The Practitioner 215: 201-207.

Title:

Editors:

SPORT AND MEDICINE

Publishers:

J. MacGregor and J. A. Moncur

E. and F. Spon, London

Price $£ 25.00$ hardback 298 pages $\quad$ ISBN 0-419-13950-8

This book is one of a series of collected papers presented at the 8th Commonwealth and International Conference on Sport, Physical Education, Dance, Recreation and Health held in Glasgow from July 18th-23rd, 1986, just before the Commonwealth Games. The organisers, editors and publishers are to be congratulated for the speed in which these proceedings were produced. There are seven sections in this book; environmental considerations, sports medicine in general, the veteran athlete, doping, the marathon, therapy and injury prevention. Most of the papers are from the UK, a large number from Scotland, but several are from the USA and others from New Zealand, Rome, Egypt, Sweden and the Irish Republic. The marathon section deals largely with experiences in various Glasgow marathons and useful information is given. Although many of the authors are well known to readers of this journal, there are many new ones and their contributions are most welcome.

The contents page, index, preface and introduction are set in type; all the individual papers have been reproduced from the authors' original typescript and some are easier to read than others. This book is a valuable contribution to sports medicine, including research that is still in progress. It is good value for the library.

H. E. Robson 